\title{
Flipbook Kesehatan di Era Pandemi sebagai Literasi Siswa Sekolah Dasar
}

\section{Myo Opidianto1*, Mei Fita Asri Untari2, Ikha Listyarini3}

1,2 Prodi Pendidikan Guru Sekolah Dasar, Universitas PGRI Semarang, Semarang, Indonesia

\section{A R T I C L E I N F O}

Article history:

Received September 02, 2021 Revised September 08, 2021

Accepted November 30, 2021

Available online December 25, 2021

Kata Kunci:

Flipbook, Kesehatan, Pandemi,

Literasi, Sekolah Dasar

Keywords:

Flipbook, Health, Pandemic, Literacy, Elementary School

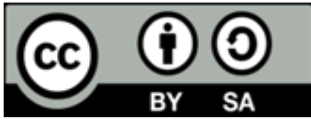

This is an open access article under the CC BY-SA license.

Copyright (ㄷ) 2021 by Author. Published by Universitas Pendidikan Ganesha.

\begin{abstract}
A B S T R A K
Literasi untuk siswa sekolah dasar merupakan hal yang sangat penting. Dalam masa pandemi seperti yang terjadi di Indonesia sejak tahun 2020 perlu adanya edukasi kesehatan untuk masyarakat, terutama siswa sekolah dasar sebagai bentuk pembahasan. Penelitian ini bertujuan untuk mengembangkan media flipbook bertema kesehatan untuk siswa sekolah dasar. Penelitian ini merupakan penelitian pengembangan yang dilaksanakan dengan menggunakan model Borg and Gall dengan penyesuaian tahapan pengembangan yaitu pendahuluan, perencanaan, pengembangan draf produk, validasi draf produk, uji coba lapangan awal. Subjek penelitian ini adalah 4 orang guru, 75 siswa dan 45 orang tua siswa. Pengumpulan data dilakukan dengan menggunakan metode wawancara, dokumentasi, serta penyebaran angket. Instrumen yang digunakan dalam penelitian ini yakni berupa lembar angket kebutuhan, angket validasi, dan angket respon. Berdasarkan hasil angket kebutuhan didapatkan hasil bahwa media flipbook dibutuhkan oleh guru, siswa, dan orang tua siswa dengan kriteria cover depan belakang serta halaman berwarna cerah dengan memilih teks yang lugas sederhana dan teks yang bervariasi. Berdasarkan hasil angket respon didapatkan hasil bahwa media flipbook kesehatan sangat cocok untuk menunjang pembelajaran daring di masa pandemi ini. Untuk memperoleh media flipbook bertema kesehatan, diesuaikan dengan hasil kebutuhan dan respon siswa, guru dan orang tua siswa. Nilai rata-rata validitas media flipbook yang diperoleh adalah 4.90 dengan kualifikasi sangat baik. Berdasarkan analisis angket respon dan kebutuhan, maka dapat disimpulkan bahwa media flipbook bertema kesehatan untuk siswa sekolah dasar dinyatakan valid dan dapat digunakan dalam pembelajaran.
\end{abstract}

A BS TRACT

Literacy for elementary school students is very important. During a pandemic like what has happened in Indonesia since 2020, it is necessary to have health education for the community, especially elementary school students as a form of discussion. This study aims to develop flipbook media with the theme of health for elementary school students. This research is development research carried out using the Borg and Gall model with adjustments to the development stages, namely introduction, planning, product draft development, product draft validation, initial field trials. The subjects of this study were 4 teachers, 75 students and 45 parents. Data collection in the study was carried out using interviews, documentation, and distributing questionnaires. The instruments used in this study were in the form of a needs questionnaire, validation questionnaire, and response questionnaire. Based on the results of the needs questionnaire, it was found that flipbook media were needed by teachers, students, and parents with the criteria for front and back covers and brightly colored pages by choosing simple plain text and varied texts. Based on the results of the response questionnaire, it was found that the health flipbook media is very suitable to support online learning during this pandemic. To obtain health-themed flipbook media in accordance with the results of the needs and responses of students, teachers and parents. The average value of flipbook media validity obtained is 4.90 with very good qualifications. Based on the response and needs questionnaire analysis, it can be concluded that the flipbook media with the theme of health for elementary school students is declared valid and can be used in learning 


\section{PENDAHULUAN}

Pandemi covid 19 telah melanda seluruh negara di dunia termasuk Indonesia. Wabah virus ini memberikan dampak pada berbagai perubahanan tananan kehidupan masyarakat. Keberadaan virus covid 19 membuat masyarakat harus membatasi aktivitas di luar rumah yang dilakukan seperti hari-hari biasa (Wakitayanti \& Hartono, 2021). Pada tanggal 12 Maret 2020 WHO (World Health Organization) menyatakan bahwa virus Covid 19 sebagai pandemi (Putri, 2020). Dengan meningkatnya jumlah kasus di Indonesia, pemerintah menerapkan kebijakan lock down dengan tujuan untuk memutus rantai penyebaran covid 19 (Hidayat, 2020; Yunus \& Rezki, 2020). Kebijakan ini telah memberikan dampak pada seluruh tatanan kehidupan masyarakat terutama di bidang sosial, ekonomi, pariwisata, dan pendidikan (Cindrakasih, 2021). Pada bidang pendidikan kebijakan ini berakibat pada terhentinya proses pendidikan secara sementara, kegiatan tatap muka dihentikan dan dialihkan dengan menggunakan pembelajaran daring (dalam jaringan) (Baharuddin, 2020; Sadikin \& Hamidah, 2020; Syarifudin, 2020).

Pendidikan harus tetap berjalan dalam keadaan apapun. Keadaan pandemi covid-19 yang terjadi mengharuskan kegiatan pendidikan tetap berjalan seperti sebelumnya. Beberapa daerah berupaya mengurangi kasus covid-19 dengan memutuskan menutup sekolah termasuk di Indonesia. Keputusan yang diterapkan pemerintah menutup sekolah dalam rangka social distancing mengharuskan pembelajaran di masa pandemi menggunakan teknologi dan internet untuk menghubungkan peserta didik dan pengajar (Asmuni, 2020; Murniati et al., 2021; Putria et al., 2020). Kondisi ini tentu tidak mudah dilalui oleh masyarakat. Orang tua juga ikut berperan sebagai guru ketika peserta didik belajar di rumah. Belajar dari rumah tentunya berbeda dengan kegiatan belajar di sekolah. Selain adanya perangkat pembelajaran, kegiatan pembelajaran juga didukung oleh kurikulum yang diterapkan saat pandemi seperti ini (Mahmudi \& Fernandes, 2021; Rasidi et al., 2021).

Kegiatan pembelajaran secara daring dilakukan dengan tujuan untuk menekan penyebaran virus covid-19 di lingkungan pendidikan. Kegiatan pembelajaran juga harus dapat merangsang tumbuhnya $4 \mathrm{C}$ yaitu (critical thinking, collaborative, creativity and communicative) pada diri peserta didik dan prasayrat wajibnya dengan kegiatan pembelajaran yang mempertimbangkan terjaganya keamanan, keselamatan dan kesehatan peserta didik dan pendidik pada aspek fisik maupun psikologi yang mengimplementasikan pembelajaran daring (Winaya, 2020). Di masa pandemi seperti saat ini, kesehatan menjadi hal yang sangat penting karean wabah covid-19 dapat menyerang kesehatan yang mempunyai imun yang rendah (Amalia et al., 2020; Nurislaminingsih, 2020). Kesehatan di masa pandemi ini tentunya menjadi poin penting bagi keberlangsungan kehidupan. Di masa pandemi ini, kesehatan menjadi pegangan hidup setiap manusia (Disantara, 2020; Mahardhani, 2020). Menerapkan hidup sehat, seperti berolahraga, makan makanan yang bergizi dan menyehatkan ialah suplemen utama bagi keberlangsungan di masa pandemi ini. Demikian juga halnya ketika berkegitan di luar rumah, setiap orang harus menerapkan protokol kesehatan yang dianjurkan pemerintah yaitu memakai masker, menjaga jarak aman, dan setiap selesai berkegiatan harus mencuci tangan dengan baik dan benar (Akbar \& Aidha, 2020; Nopiyanto et al., 2020). Pembentukan kebiasaan yang sehat pada peserta didik harus dapat dilaksanakan dengan baik dan benar melalui pendampingan orang tua maupun guru. Peserta didik mendapatkan ilmu dan pengetahuan mengenai kebiasaan hidup sehat di masa pandemi. Peningkatan kualitas hidup anak salah satunya ditentukan oleh penanaman perilaku kesehatan sejak dini.

Guru sebagai seorang pendidikan dituntut mampu menanamkan pola-pola hidup sehat kepada siswa agar siswa terhindar dari paparan virus covid-19. Hanya saja berdasarkan hasil observasi dan wawancara dengan guru di beberapa sekolah dasar Kecamatan Pedurungan Kota Semarang, Jawa Tengah diperoleh hasil bahwa guru belum mampu menanamkan kebiasaan-kebiasaan hidup sehat di masa pandemi kepada siswa. Hal ini dikarenakan kurangnya ketersediaan media yang mampu menyampaikan pesan hidup sehat dengan menarik. Beberapa buku panduan atau sumber yang diberikan belum interaktif dengan peserta didik karena hanya berupa uraian materi yang berkaitan tentang kesehatan. Menurut guru di SD Kalicari 1 perlu adanya media khusus yang memperkenalkan pencegahan kesehatan di masa pandemi terhadap peserta didik sejak dini. Penggunaan media pembelajaran dalam proses pembelajaran dapat menumbuhkan minat baru dan rangsangan proses pembelajaran serta mampu membangkitkan motivasi siswa. Selain menumbuhkan minat baru, dalam pemilihan media, guru juga harus memerhatikan materi pembelajaran agar media sesuai dengan materi pembelajaran yang dibahas.

Salah satu media yang dapat digunakan untuk meningkatkan literasi kesehatan siswa yakni media berupa flipbook. Flipbook merupakan suatu media yang dibuat dari beberapa lembaran-lembaran kertas yang kemudian disusun menyerupai album atau kalender dengan berbagai ukuran (Elvianasti \& Dharma, 2019; Kurniawan, 2017). Setiap halaman pada media flipbook dapat ditambahkan gambar serta materi yang menarik sesuai dengan kreasi pengembang (Wibowo \& Pratiwi, 2018). Media flipbook memiliki beberapa kelebihan di antaranya adalah dapat menyajikan materi pembelajaran dalam bentuk kata-kata, kalimat dan gambar, dapat dilengkapi dengan warna-warna, sehingga lebih menarik perhatian siswa, 
mudah dibuat dan harganya murah, mudah dibawa ke mana-mana, dan dapat meningkatkan aktivitas belajar siswa (Diani \& Hartati, 2020). Di masa pandemi seperti saat ini media pembelajaran sangatlah dibutuhkan untuk menumbuhkan minat baru dan rangsangan proses pembelajaran serta mampu memotivasi peserta didik.

Beberapa penelitian yang telah dilakukan sebelumnya menyebutkan bahwa flipbook digital merupakan salah satu solusi alternatif guna menunjang pembelajaran siswa di era revolusi industry 4.0. Pembelajaran akan sangat bervariasi dan menarik dari segi tampilan visual maupun secara audiovisual, sehingga media ini sangat layak untuk dikembangkan (Amanullah, 2020). Penelitian selanjutnya juga menyebutkan bahwa media pembelajaran Flipbook layak digunakan pada proses pembelajaran karena media ini dapat meningkatkan kemampuan pemahaman materi siswa (Nuryani \& Abadi, 2021). Penelitian lainnya menyebutkan bahwa media flipbook berbasis PBL sangat efektif digunakan untuk melatihkan keterampilan berpikir kritis pada materi pencemaran lingkungan yang telah dikembangkan layak secara teoretis dan empiris untuk digunakan dalam pembelajaran (Agustina \& Fitrihidajati, 2020).

Berdasarkan beberapa hasil penelitian tersebut dapat dikatakan bahwa media flipbook merupakan media yang efektif untuk dikembangkan. Media ini dapat meningkatkan kemampuan kognitif serta kemampuan berpikir kritis siswa. Hanya saja pada penelitian sebelumnya belum terdapat kajian mengenai pengembangan media flipbook kesehatan di masa pandemi, sehingga penelitian ini difokuskan pada hal tersebut dengan tujuan untuk mengembangkan media flipbook bertema kesehatan untuk siswa sekolah dasar.

\section{METODE}

Penelitian ini merupakan jenis penelitian pengembangan yang dilakukan untuk mengembangkan produk baru atau menyempurnakan produk yang telah ada. Pengembangan media dilakukan dengan menggunakan model Borg and Gall dengan penyesuaian yaitu melakukan studi pendahuluan, perencanaan, pengembangan draf produk, validasi draf produk, uji coba lapangan awal. Namun pada tahap ini hanya sampai uji coba produk lapangan awal. Subjek yang terlibat dalam penelitian ini yakni 4 orang guru, 75 siswa, dan 45 orang tua siswa. Pengumpulan data dalam penelitian dilakulan dengan menggunakan metode observasi, wawancara, dan kuesioner. Instrumen yang digunakan dalam penelitian yakni berupa lembar angket analisis kebutuhan peserta didik, kebutuhan guru, serta lembar angket kebutuhan orang tua. Media flipbook yang telah dikembangkan selanjutnya dilakukan uji coba produk untuk mengetahui kevalidan media. Desain uji coba dalam penelitan ini melalui tahap review dari ahli media dan materi untuk mengetahui validitas media flipbook yang telah di kembangkan. Setelah di review oleh ahli, data hasil review kemudian dianalisis berdasarkan data yang didapatkan. Hasil data uji validasi kemudian dihitung persentasenya dengan menggunakan rumus persentase yang kemudian diklasifikasikan ke dalam tabel kriteria validitas dan efektivitas.

\section{HASIL DAN PEMBAHASAN}

Hasil

Penelitian ini dilaksanakan untuk mengembangkan media flipbook pada era pandemi untuk menunjang pembelajaran daring siswa sekolah dasar. Hasil penlitian ini adalah media flipbook yang sudah valid. Hasil tersebut diperoleh melalui tahap melakukan studi pendahuluan, perencanaan, pengembangan draf produk, validasi draf produk, uji coba lapangan awal.

Tahap analisis terdiri dari analisis kebutuhan, analisis media yang baik dan analisis karakteristik peserta didik. Analisis kebutuhan dilakukan dengan menyebarkan kuesioner kepada siswa, guru dan orang tua siswa di 3 SD di Kota Semarang. Hasilnya, 97\% siswa menyatakan sangat setuju dan $97 \%$ siswa menyatakan setuju apabila ada media pembelajaran mengenai pencegahan penyakit di masa pandemi dalam media flipbook. sedangkan $98 \%$ guru menyatakan bahwa materi muatan IPA tentang kesehatan pada buku sangat perlu dikembangkan ke dalam bentuk flipbook. Analisis karakteristik peserta didik digunakan untuk mengetahui karakteristik peserta didik yang akan menggunakan media. Analisis media yang baik menggunakan analisis kriteria media yang baik untuk SD.

Pada tahap perencanaan dilakukan proses peninjauan materi pembelajaran yang berpedoman pada Kompetensi Dasar, Kompetensi Inti serta membaca buku sumber yang berkaitan dengan pembelajaran. Mengkaji materi tentang media flipbook sebagai pondasi untuk memilih desain dan bentuk media pembelajaran. perencanaan desain media flipbook yang dimulai dari menentukan materi yang akan akan dikembangkan. Dalam media flipbook, dibuat rancangan flipbook menggunakan bantuan applikasi canva dan anyflip, kemudian dikonsultasikan dengan dosen pembimbing untuk mendapatkan masukan atau saran agar bisa dilakukan perbaikan. Setelah dosen pembimbing menyutujui kemudian dilanjutkan ke tahap pengembangan. 
Tahap pengembangan produk diawali dengan menyusun instrumen penilaian media flipbook dengan metode kuesioner yang nantinya akan disebarkan kepada siswa, guru serta orang tua siswa di 3 sekolah yang berbeda. Selanjutnya, dilakukan validasi instrumen. Tahap ini dilakukan setelah disusun instrumen penilaian yang nantinya akan divalidasi oleh tenaga ahli atau validator agar valid untuk dibagikan kepada siswa, guru, serta orang tua siswa. Selanjutnya, dilakukan validasi kepada ahli media dan materi untuk dapat mengetahui kelayakan media flipbook bertema kesehatan. Tahap ini dilaksanakan diawali dengan pengembangan media sesuai dengan rancangan yang telah disetujui oleh dosen pembimbing. Media dikembangkan dengan sampul yang menarik, warna yang lembut. dilengkapi dengan teks cerita serta tokoh animasi, dan terdapat latihan soal pada halaman terakhir. Setelah media selesai dikembangkan, tahap selanjutnya yaitu melakukan uji coba terbatas media untuk mengetahui validitas media yang dikembangkan. Hasil pengujian validitas media flipbook bertema kesehatan untuk siswa sekolah dasar yang diperoleh disajikan pada Tabel 1.

Tabel 1. Hasil Validasi Media Flipbook

\begin{tabular}{|c|c|c|c|c|}
\hline \multirow{2}{*}{ No. } & \multirow{2}{*}{ Butir Penilaian } & \multicolumn{3}{|c|}{ Skor } \\
\hline & & Ahli (1) & Ahli (2) & Ahli (3) \\
\hline 1 & Media flipbook memiliki tampilan yang menarik & 4 & 5 & 5 \\
\hline 2 & Kejelasan gambar pada media flipbook & 4 & 5 & 4 \\
\hline 3 & Keserasian warna pada media flipbook & 3 & 5 & 4 \\
\hline 4 & $\begin{array}{l}\text { Warna yang terdapat pada media flipbook menarik bagi } \\
\text { siswa }\end{array}$ & 3 & 5 & 5 \\
\hline 5 & Teks dalam media flipbook dapat terbaca jelas & 3 & 5 & 3 \\
\hline 6 & Media flipbook sesuai untuk kelas 2 SD & 4 & 5 & 5 \\
\hline 7 & $\begin{array}{l}\text { Media flipbook mudah digunakan } \\
\text { (dengan pendampingan guru/orang tua) }\end{array}$ & 3 & 5 & 3 \\
\hline 8 & Media flipbook sesuai dengan karakteristik kelas 2 & 4 & 5 & 4 \\
\hline 9 & Penyajian media dapat menarik siswa & 4 & 5 & 5 \\
\hline 10 & Media flipbook praktis (mudah digunakan) & 4 & 5 & 3 \\
\hline 11 & Penyajian media flipbook jelas & 4 & 5 & 4 \\
\hline 14 & $\begin{array}{l}\text { Media flipbook menambah konsentrasi siswa dalam proses } \\
\text { pembelajaran }\end{array}$ & 4 & 5 & 5 \\
\hline 15 & $\begin{array}{l}\text { Media flipbook memiliki tahapan membaca, menyimak dan } \\
\text { mendengarkan }\end{array}$ & 4 & 5 & 5 \\
\hline & Rata -Rata Ahli & 5.60 & 7.50 & 6.00 \\
\hline & Rata-Rata Keseluruhan & & 6,36 & \\
\hline
\end{tabular}

Hasil analisis data berupa rata-rata skor validitas media flipbook oleh 3 orang ahli atau validator flipbook bertema kesehatan di masa pandemi untuk siswa sekolah dasar menunjukkan bahwa skor ratarata ahli 1 sebesar 5.60, skor rata-rata ahli 2 sebesar 7.50, dan skor rata-rata ahli 3 sebesar 6.00. Sedangkan validitas media flipbook memperoleh skor rata-rata keseluruhan sebesar 6.36. Berdasarkan kualifikasi skala lima, maka media flipbook berkualifikasi "Sangat Baik".

Adapun tampilan media flipbook bertema kesehatan di masa pandemi untuk siswa sekolah dasar dapat dilihat pada Gambar 1, 2, 3, 4, dan 5

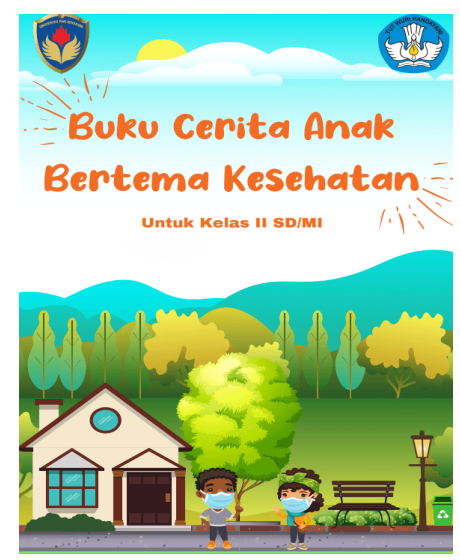

Gambar 1. Cover Buku 


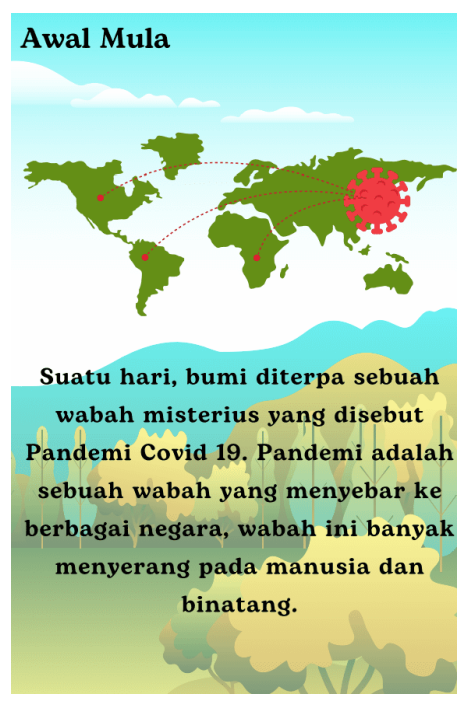

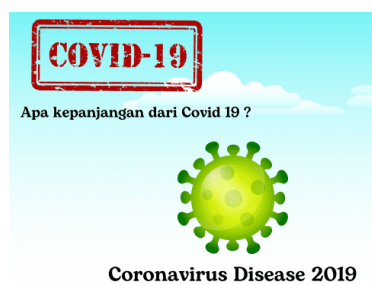

Covid 19 adalah virus baru yang ditemukan dikota Wuhan, Tiongkok. Umumnya Virus ini dapat mengakibatkan gejala gangguan pernapasan akut seperti demam dan sesak$$
\text { Virus ini dapat menular melalui percikan air }
$$
liur serta kondisi lingkungan disekitar manusia itu sendiri.

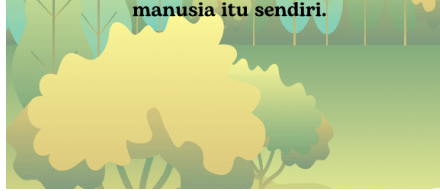

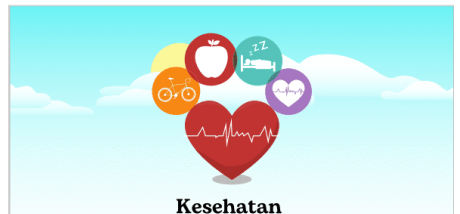

Kesehatan adalah kondisi fisik atau mental yang sehat dan tidak adanya penyakit, jadi manusia yang mempunyai kesehatan yang baik dapat melakukan aktifitas dengan semaksimal

mungkin dan tidak adanya kelemahan atau sakit sedikit pun.

Menjaga pola hidup bersih dan sehat dapat meningkatkan imunitas pada tubuh manusia agar daya tahan tubuh tetap terjaga dan tidak dapat terserang penyakit.

Gambar 2. Bagian Awal
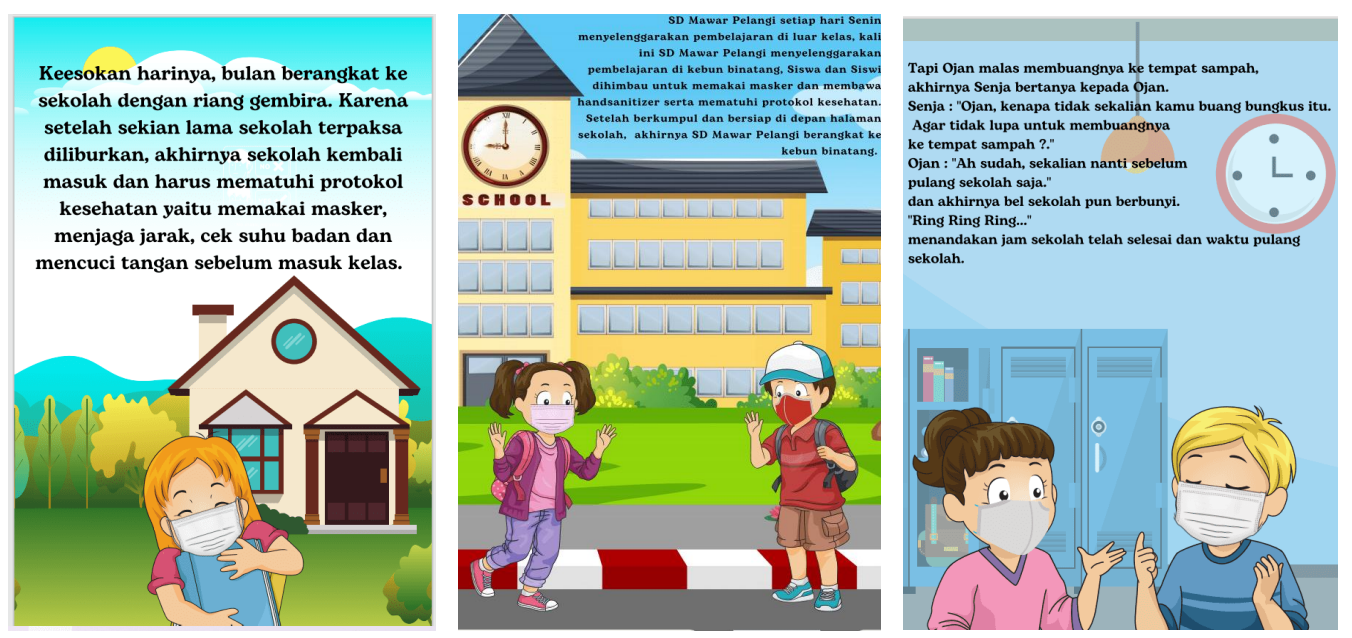

Gambar 3. Bagian Aktivitas Sehari-hari

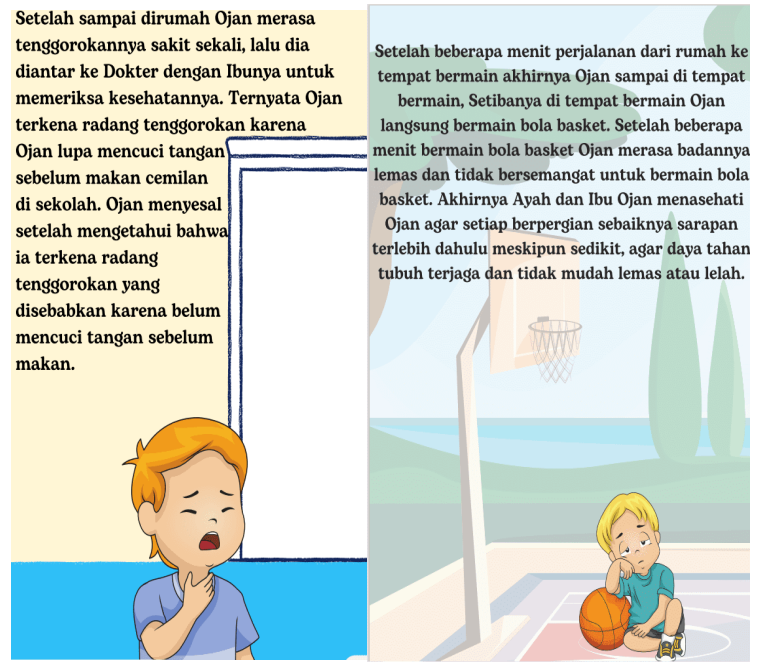

Gambar 4. Dampak tidak Menjaga Kesehatan

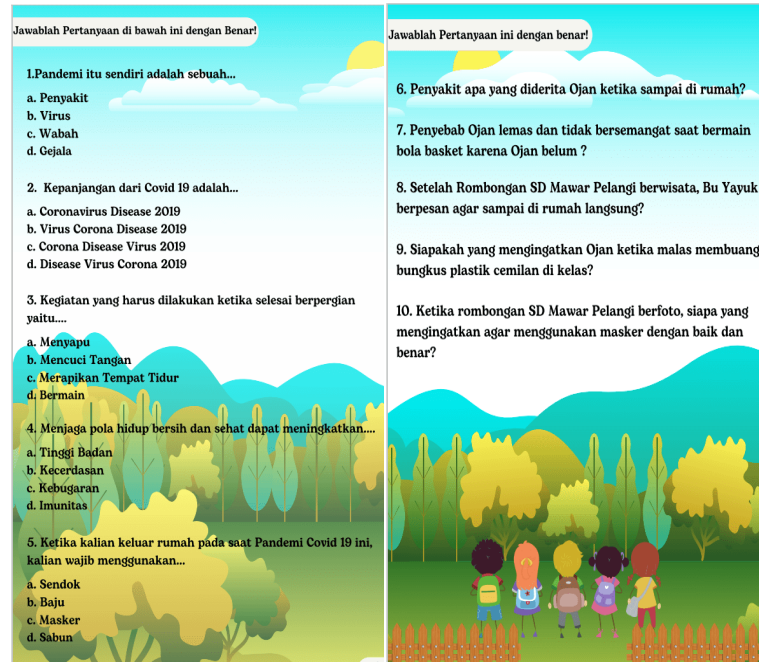

Gambar 5. Penutup 


\section{Pembahasan}

Penelitian pengembangan ini mengahasilkan sebuah prduk media flipbook kesehatan yang telah teruji validitasnya, sehingga layak diberikan kepada siswa sekolah dasar. Terdapat beberapa faktor yang mendukung keberhasilan pengembangan media flipbook kesehatan. Faktor pertama yakni media flipbook kesehatan yang dikembangan telah sesuai dengan kebutuhan siswa dan guru saat ini. Seperti yang telah diketahui bersama bahwa di masa pandemi seperti saat ini kesehatan menjadi hal yang paling penting. Dengan diterapkannya pola hidup sehat maka seseorang akan terhindar dadi paparan virus covid-19 (Intan et al., 2021; Murtiningsih, 2020). Selain dianjurkan untuk menerapkan pola hidup sehat, di masa pandemi seperti saat ini masyarakat juga dianjurkan untuk menerapkan 3M, yakni menjaga jarak, menggunakan masker, serta mencuci tangan (Cahyanto et al., 2021; Novalia \& Handayani, 2021). Pola hidup yang sehat serta sesuai dengan anjuran pemerintah akan menekan proses penyebaran virus covid19. Hal ini akan berdampak pada kestabilan kondisi perekonomian, kesehatan, serta pendidikan di Indonesia (Mahardhani, 2020).

Faktor pendukung keberhasilan pengembangan media yang kedua yakni media flipbook yang dikembangakan memiliki desain gambar serta warna yang menarik. Desain, gambar, serta warna yang menarik merupakan salah satu komponen penunjung keberhasilan pengembangan suatu media. Dengan desain yang menarik, siswa akan tertarik melihat isi media tersebut (Amanullah, 2020; Wibowo \& Pratiwi, 2018). Hal ini didukung oleh penggunaan bahasa serta warna dasar yang nyaman saat dibaca siswa (Nuryani \& Abadi, 2021). Selain penggunana desain, gambar, serta warna yang menarik (Amiyanti \& Ningsih, 2018; Daningsih \& Yokhebed, 2017), keberhasilan media juga dapat dilihat dari penggunaan bahasa. Media yang diperuntukan kepada siswa sekolah dasar akan lebih baik jika menggunakan bahasa yang mudah dimengerti, sehingga siswa dengan mudah memahami pesan yang hendak disampaikan melalui media tersebut (Nurrohman, 2021).

Faktor ketiga, media flipbook dapat meningkatkan kemampuan literasi siswa. Literasi diartikan sebagai kemampuan belajar yang dilakukan untuk mengakses ilmu pengetahuan melalui membaca. Liiterasi juag berarti kemampuan menggunakan keterampilan membaca dalam hal mendapatkan akses ke dunia pengetahuan untuk mendapatkan informasi dari berbagai sumber, untuk mengevaluasi argumen, dan juga belajar subjek yang benar-benar baru (Ainiyah, 2017; Widayoko et al., 2018). Pelaksanaan kegiatan literasi membaca bertujuan memperkenalan siswa tentang dasar - dasar membaca dan menulis, memelihara kesadaran bahasa, dan motivasi untuk belajar (Husna \& Marlini, 2019). Media flipbook ini akan dapat meningkatkan kemampuan literasi siswa mengenai kesehatan pasca terjadinya virus pandemi, sehingga nantinya siswa akan dapat menjaga kesehatannya secara mandiri.

Hasil yang diperoleh pada penelitian ini sejalan dengan hasil penelitian terdahulu yang juga menyebutkan bahwa flipbook digital merupakan salah satu solusi alternatif guna menunjang pembelajaran siswa di era revolusi industry 4.0. Pembelajaran akan sangat bervariasi dan menarik dari segi tampilan visual maupun secara audiovisual, sehingga media ini sangat layak untuk dikembangkan (Amanullah, 2020). Penelitian selanjutnya juga menyebutkan bahwa media pembelajaran Flipbook layak digunakan pada proses pembelajaran karena media ini dapat meningkatkan kemampuan pemahaman siswa terhadap materi yang dipelajarinya (Nuryani \& Abadi, 2021). Penelitian lainnya menyebutkan bahwa media flipbook berbasis PBL sangat efektif digunakan untuk melatihkan keterampilan berpikir kritis pada materi pencemaran lingkungan yang telah dikembangkan layak secara teoretis dan empiris untuk digunakan dalam pembelajaran (Agustina \& Fitrihidajati, 2020). Berdasarkan beberapa hasil penelitian tersebut dapat dikatakan bahwa media flipbook merupakan media yang sangat layak dikembangkan karena mampu memberikan aspek positif terhadap berbagai pengembangan kemampuan siswa.

\section{SIMPULAN}

Berdasarkan hasil penelitian dan pembahasan dapat disimpulkan bahwa media flipbook bertema kesehatan di masa pandemi untuk siswa sekolah dasar memiliki klasifikasi sangat baik. Media ini sangat layak dikembangkan dan diperkenalkan kepada siswa melalui pembelajaran mengenai kesehatan di masa pandemic covid-19.

\section{DAFTAR RUJUKAN}

Agustina, D. W., \& Fitrihidajati, H. (2020). Pengembangan Flipbook Berbasis Problem Based Learning (PBL) pada Submateri Pencemaran Lingkungan untuk Melatihkan Keterampilan Berpikir Kritis Peserta Didik Kelas X SMA. BioEdu: Berkala Ilmiah Pendidikan Biologi, 9(1), 325-339. https: //ejournal.unesa.ac.id/index.php/bioedu/article/view/36757/32588. 
Ainiyah, N. (2017). Membangun Penguatan Budaya Literasi Media dan Informasi dalam Dunia Pendidikan. Jurnal Pendidikan Islam Indonesia, 2(1), 65-77. https://doi.org/10.35316/jpii.v2i1.63.

Akbar, D. M., \& Aidha, Z. (2020). Perilaku Penerapan Gizi Seimbang Masyarakat Kota Binjai pada Masa Pandemi Covid-19 Tahun 2020. Menara Medika, 3(1). https://doi.org/10.31869/mm.v3i1.2193.

Amalia, L., Irwan, I., \& Hiola, F. (2020). Analisis Gejala Klinis dan Peningkatan Kekebalan Tubuh untuk Mencegah Penyakit Covid-19. Jambura Journal of Health Sciences and Research, 2(2), 71-76. https://doi.org/10.35971/jjhsr.v2i2.6134.

Amanullah, M. A. (2020). Pengembangan Media Pembelajaran Flipbook Digital Guna Menunjang Proses Pembelajaran di Era Revolusi Industri 4.0. Jurnal Dimensi Pendidikan Dan Pembelajaran, 8(1), 37. https://doi.org/10.24269/dpp.v0i0.2300.

Amiyanti, R., \& Ningsih, K. (2018). Pengaruh Model Kooperatif Berbantuan Media Flipbook terhadap Hasil Belajar Siswa Kelas x SMAN 3 Materi Bakteri. Jurnal Pendidikan Dan Pembelajaran Khatulistiwa, 1(1), 0-9. http://jurnal.untan.ac.id/index.php/jpdpb/article/view/27062/75676577671.

Asmuni, A. (2020). Problematika Pembelajaran Daring di Masa Pandemi Covid-19 dan Solusi Pemecahannya. Jurnal Paedagogy, 7(4), 281. https://doi.org/10.33394/jp.v7i4.2941.

Baharuddin, I. (2020). Pembelajaran Bermakna Berbasis Daring di Tengah Pandemi Covid-19. Journal of Islamic Education Management, 5(2), 79-88. https://doi.org/10.24256/kelola.v5i2.1377.

Cahyanto, B., Sholihah, L. K., Hamidah, N., Sari, E. D. W., \& Wati, A. K. (2021). Penyuluhan Kesehatan Masyarakat untuk Meningkatkan Kesadaran Pola Hidup Bersih dan Sehat (PHBS) di Era Pandemi Covid-19. Jurnal Pembelajaran Pemberdayaan Masyarakat, 2(1). https://doi.org/10.33474/jp2m.v2i1.10787.

Cindrakasih, rosita. (2021). Dampak COVID- 19 terhadap Sosial Budaya dan Gaya Hidup Masyarakat. Jurnal Public Relation, 2(2). https://doi.org/10.31294/jpr.v2i2.385.

Daningsih, E., \& Yokhebed. (2017). Kelayakan Media Flipbook Upaya pencegahan Pencemaran Udara Kelas x. Jurnal Program Studi Pendidikan Biologi FKIP Untan, 7(2), 1-11. https://docplayer.info/203863586-Kelayakan-media-flipbook-upaya-pencegahan-pencemaranudara-kelas-x.html.

Disantara, F. P. (2020). Tanggung Jawab Negara dalam Masa Pandemi Covid-19. JCH (Jurnal Cendekia Hukum), 6(1), 48. https://doi.org/10.33760/jch.v6i1.262.

Elvianasti, M., \& Dharma, A. P. (2019). Pelatihan Pembuatan Media Flipbook bagi Guru Sma Muhammadiyah Se-Dki Jakarta. Abdimas Universal, 1(1), 6-10. https://doi.org/10.36277/abdimasuniversal.v1i1.2.

Hidayat, risyal hardiyanto. (2020). Strategic Steps to Prevent COVID-19 Pendemi at the Indonesian Correctional Institution. Jurnal Pendidikan Kesehatan (E-Journal), 9(1). https://doi.org/10.31290/jpk.v9i1.1494.

Husna, M. A., \& Marlini, M. (2019). Rancangan Kegiatan Literasi Informasi di SMA Negeri 1 Padang. Ilmu Informasi Perpustakaan Dan Kearsipan, 8(1), 242. https://doi.org/10.24036/107345-0934.

sIntan, T., Hasanah, F., Wardiani, S. R., \& Handayani, V. T. (2021). Peningkatan Kualitas Hidup di Masa Pandemi Covid-19 dengan Penerapan Pola Hidup Sehat. Jurdimas (Jurnal Pengabdian Kepada Masyarakat) Royal, 4(1), 27-32. https://doi.org/10.33330/jurdimas.v4i1.834.

Kurniawan, D. T. (2017). Penggunaan Model PJBL untuk Meningkatkan Kreativitas Mahasiswa dalam Membuat Media Pembelajaran Matematika. Kalamatika Jurnal Pendidikan Matematika, 2(2), 207. https://doi.org/10.22236/KALAMATIKA.vol2no2.2017pp207-220.

Mahardhani, A. januar. (2020). Menjadi Warga Negara yang Baik pada Masa Pandemi Covid-19: Persprektif Kenormalan Baru. Jurnal Pancasila Dan Kewarganegaraan, 5(2), 65-76. https://doi.org/10.24269/jpk.v5.n2.2020.pp65-76.

Mahmudi, W., \& Fernandes, reno. (2021). Adaptasi Siswa tehadap Pola Pembelajaran Daring pada Masa Pandemi Covid-19 di SMAN 1 Solok. Jurnal Perspektif: Jurnal Kajian Sosiologi Dan Pendidikan, 4(3). https://doi.org/10.24036/perspektif.v4i3.471.

Murniati, R. F., Gis, M., \& Nuwaswita, L. (2021). Dilematis antara Kesulitan Siswa dan Guru dalam Pembelajaran Daring pada Masa Pandemic Covid-19: Sebuah Upaya Aksidental MTs. Muhammadiyah Wuring Authors. Naturalistic: Jurnal Kajian Penelitian Dan Pendidikan Dan Pembelajaran, 6(1). https://doi.org/10.35568/naturalistic.v6i1.902.

Murtiningsih, M. (2020). Penyuluhan Kesehatan Pola Hidup Sehat secara Daring Menggunakan Zoom dan Youtube sebagai Media Ajar pada Masa Pandemi COVID-19. Jurnal Pengabdian Nasional (JPN) Indonesia, 1(2), 37-40. https://doi.org/10.35870/jpni.v1i2.13.

Nopiyanto, Y. E., Raibowo, S., Sugihartono, T., \& Yarmani, Y. (2020). Pola Hidup Sehat dengan Olahraga dan Asupan Gizi untuk Meningkatkan Imun Tubuh Menghadapi Covid-19. Dharma Raflesia : Jurnal Ilmiah Pengembangan Dan Penerapan IPTEKS, 18(2), 90-100. 
https: //doi.org/10.33369/dr.v18i2.13008.

Novalia, P. D., \& Handayani, L. (2021). Gambaran Penerapan Protokol Kesehatan 3m di Masyarakat pada Masa Pandemi Covid-19: Literature Review. Visikes: Jurnal Kesehatan Masyarakat, 20(2). https://doi.org/10.33633/visikes.v20i2.4653.

Nurislaminingsih, R. (2020). Layanan Pengetahuan tentang COVID-19 di Lembaga Informasi. Tik Ilmeu : Jurnal Ilmu Perpustakaan Dan Informasi, 4(1), 19. https://doi.org/10.29240/tik.v4i1.1468.

Nurrohman, A. (2021). Analisis Edugame Berbasis Android sebagai Media Pembelajaran di Sekolah Dasar. $\begin{array}{llll}\text { Sinasis } & \text { (Seminar } & \text { Nains), } & \text { 2(1). }\end{array}$ http://www.proceeding.unindra.ac.id/index.php/sinasis/article/view/5349.

Nuryani, L., \& Abadi, I. G. surya. (2021). Media Pembelajaran Flipbook Materi Sistem Pernapasan Manusia pada Muatan IPA Siswa Kelas V SD. Jurnal Imiah Pendidikan Dan Pembelajaran, 5(2), 247. https: //doi.org/10.23887/jipp.v5i2.32934.

Putri, R. N. (2020). Indonesia dalam Menghadapi Pandemi Covid-19. Jurnal Ilmiah Universitas Batanghari Jambi, 20(2), 705. https://doi.org/10.33087/jiubj.v20i2.1010.

Putria, H., Maula, L. H., \& Uswatun, D. A. (2020). Analisis Proses Pembelajaran dalam Jaringan (DARING) Masa Pandemi Covid- 19 pada Guru Sekolah Dasar. Jurnal Basicedu, 4(4), 861-870. https://doi.org/10.31004/basicedu.v4i4.460.

Rasidi, M. A., Hikmatullah, N., \& Sobry, M. (2021). Hambatan Guru dalam Pembelajaran Daring: Studi Kasus di Kelas V MIN 2 Kota Mataram. Jurnal Ilmiah Pendidikan Dasar, 8(2), 159. https://doi.org/10.30659/pendas.8.2.159-174.

Sadikin, A., \& Hamidah, A. (2020). Pembelajaran Daring di Tengah Wabah Covid-19. Biodik, 6(2), 109-119. https: //doi.org/10.22437/bio.v6i2.9759.

Syarifudin, A. S. (2020). Impelementasi Pembelajaran Daring untuk Meningkatkan Mutu Pendidikan sebagai Dampak Diterapkannya Social Distancing. Jurnal Pendidikan Bahasa Dan Sastra Indonesia Metalingua, 5(1), 31-34. https://doi.org/10.21107/metalingua.v5i1.7072.

Wakitayanti, N. A., \& Hartono, M. (2021). Motivasi dan Kesadaran Hidup Sehat Masyarakat untuk Berolahraga pada Masa New Normal di Kota Semarang. Indonesian Journal for Physical Education and Sport, 2(1). https: //doi.org/10.15294/INAPES.V2I1.43230.

Wibowo, E., \& Pratiwi, D. D. (2018). Pengembangan Bahan Ajar Menggunakan Aplikasi Kvisoft Flipbook Maker Materi Himpunan. Desimal: Jurnal Matematika, 1(2), 147. https://doi.org/10.24042/djm.v1i2.2279.

Widayoko, A., H, S. K., \& Muhardjito, M. (2018). Analisis Program Implementasi Gerakan Literasi Sekolah (GLS) dengan Pendekatan Goal-Based Evaluation. Jurnal Tatsqif, 16(1), 78-92. https://doi.org/10.20414/jtq.v16i1.134.

Winaya, I. M. A. (2020). Pengembangan Nilai-Nilai Karakter Anak pada Pembelajaran Jarak Jauh di Masa Pademi Covid-19 Dengan Berbantu Lembar Kejra Siswa Berbasis Proyek. Jurnal Pendidikan Kewarganegaraan Undiksha, 8(1), 35-46. https://ejournal.undiksha.ac.id/index.php/JJPP/article/view/23548/14372.

Yunus, N. R., \& Rezki, A. (2020). Kebijakan Pemberlakuan Lock Down sebagai Antisipasi Penyebaran Corona Virus Covid-19. SALAM: Jurnal Sosial Dan Budaya Syar-I, $7(3)$. https://doi.org/10.15408/sjsbs.v7i3.15083. 